\title{
Analisis Metode Montessori dalam Meningkatkan Kemampuan Membaca Permulaan Siswa Kelas Rendah SD/MI
}

\author{
Nura Azkia ${ }^{1}$, Nur Rohman ${ }^{2}$ \\ ${ }^{12}$ Universitas Islam Negeri Sunan Kalijaga Yogyakarta \\ nuraazkia18@gmail.com,rohmaan.707@gmail.com
}

\begin{abstract}
Reading is the highest function that comes from the human brain. Reading as a basic foundation in academic ability. Therefore the introduction of the letter 'reading' as a first step to teach children / students in knowing, understanding, and inferring the meaning of reading. The purpose of this study provides a new concept of the montessori method in reading the beginning of children / students in Indonesian language lessons in low grades. This library research will explain validly and objectively about the related analysis. The research relies on sources from various established bibliographies such as scientific articles, theses and books. Then integrated into the substance of research or content analysis. The results of this study are: (1) providing a new pattern in stimulating understanding in reading the beginning of children/ students, (2) providing concepts in strengthening the absorption reading the beginning of children/students, (3) meeting the needs in the period sensitive and intellectual structure in learning to read the beginning of children/ students, (4) Development of new materials on the montessori method in concrete Indonesian language learning to improve the ability to read the beginning of children/students.
\end{abstract}

Keywords: Montessori Method, Reading the Beginning.

Abstrak: Membaca merupakan fungsi tertinggi yang berasal dari otak manusia. Membaca sebagai pondasi dasar dalam kemampuan akademik. Oleh karenanya pengenalan huruf 'bacaan' sebagai langkah awal untuk mengajarkan anak/peserta didik dalam mengetahui, memahami, dan menyimpulkan makna bacaan. Tujuan penelitian ini memberikan konsep baru tentang metode montessori dalam membaca permulaan anak/peserta didik pada pelajaran Bahasa Indonesia di kelas rendah. Studi pustaka (library research) ini akan menjelaskan secara valid dan objektif tentang analisis yang terkait. Adapun penelitian ini mengandalkan sumber dari berbagai bibliografi yang mapan seperti artikel ilmiah, skripsi dan buku. Kemudian diintegrasikan pada substansi penelitian atau analisis isi (analysis content). Adapun hasil penelitian ini yakni: (1) memberikan pola baru dalam merangsang pemahaman dalam membaca permulaan anak/peserta didik, (2) memberikan konsep dalam penguatan daya serap (Absorbent mind) membaca permulaan anak/peserta didik, (3) memenuhi kebutuhan pada periode sensitif

AR-RIAYAH : Jurnal Pendidikan Dasar vol. 4, no. 1, 2020

IAIN Curup - Bengkulu l p ISSN 2580-362X; e ISSN 2580-3611 http://journal.iaincurup.ac.id/index.php/JPD 
serta struktur intelektual dalam belajar membaca permulaan anak/peserta didik, (4) Pengembangan material baru pada metode montessori dalam pembelajaran bahasa Indonesia yang konkrit untuk meningkatkan kemampuan membaca permulaan anak/peserta didik.

Kata Kunci Metode Montessori, Membaca Permulaan.

\section{PENDAHULUAN}

Pondasi dasar kemampuan akademik adalah keterampilan membaca. ${ }^{1}$ Membaca adalah fungsi tertinggi yang berasal dari otak manusia ${ }^{2}$ sehingga dapat dikatakan bahwa setiap proses belajar didasarkan pada kemampuan membaca. ${ }^{3}$.Membaca menjadi media bagi anak untuk mengetahui dan mencari informasi. ${ }^{4}$ Pengenalan huruf merupakan salah satu langkah awal mengajarkan anak agar mampu membaca dengan baik. ${ }^{5}$ Pengenalan huruf ini merupakan dasar yang diperlukan agar anak mampu membaca

1 Epcacan, C. Socio Economic And Cultural Factors Effecting Self Efficacy On Reading Comperehension, (Procedia Social And Behavioral Sciences, 2010), Hal. 666671. Lihat Juga Aguswan Khotibul Umam, "Dukungan Lingkungan Literasi Keluarga Muslim Terhadap Perkembangan Kemampuan Membaca Latin Dan Arab (Alqur'an) Serta Perkembangan Akademik Anak", Elementary:Jurnal Ilmiah Pendidikan Dasar, 2 (1) (2016): 1-12. Hal. 1. Link. http://ejournal.metrouniv.ac.id/index.php/elementary/article/view/dukunganlingkungan-literasi-keluarga-muslim-terhadap-perkembangan-kemampuanmembaca-latin-dan-alqur\%092an-serta-perkembangan-akademik-anak

2 Rolldan. Aurora H. College Reading And Writing, (Greenhill: Reading Dinamics, 1975). Hal. 1 Lihat Juga Matlin, Margaret W. Cognition, (Northwestern University: Wiley, 2008). Hal. 19. Lihat juga Chairunnisa, "Pengaruh Literasi Membaca Dengan Pemahaman Bacaan" (Penelitian Survei Pada Mahasiswa STKIP Kusumanegara Jakarta), Jurnal Pendidikan Bahasa Sekolah Pascasarana, 6 (1) (2017): 745-756. Hal. 756. Link. http://jurnal.unswagati.ac.id/ index.php/jurnaltuturan/article/view/1584/963

3 Farida Rahim, Pengajaran Membaca Di Sekolah Dasar (Jakarta: PT Bumi Aksara., 2007), Hal. 2

$4 \mathrm{~S}$ Ameliola, HD Nugraha, Perkembangan Media Informasi Dan Teknologi Terbadap Anak Dalam Era Globalisasi, $2013 . \quad$ Link. http://www.academia.edu/download/34462625/2013-02-29.pdf Diakses 12 September 2014.

5 Seefeldt, Carol. Barbara A. Wasik. Pendidikan Anak Usia Dini Menyiapkan Anak Usia Tiga, Empat, Dan Lima Tabun Masuk Sekolah. (Jakarta: PT Indeks 2008) Lihat Juga Ema Pratiwi, "Pembelajaran Calistung Bagi Anak Usia Dini Antara Manfaat Akademik Dan Resiko Menghambat Kecerdasan Mental Anak". Prosiding Seminar Nasional Pendidikan "Inovasi Pembelajaran Untuk Pendidikan Berkemajuan" Fkip Universitas Mubammadiyah Ponorogo, 7 November 2015:278-283. Link . http://seminar.umpo.ac.id/index.php/semnasdik2015/article/viewFile/231/231 
serangkaian huruf dengan baik. Tanpa mengenali huruf, anak tidak mungkin dapat membaca suatu teks kalimat ataupun membaca kata dengan baik. ${ }^{6}$ Ditambah lagi huruf-huruf vokal merupakan pelajaran mendasar yang harus dikuasai oleh anak/peserta didik. ${ }^{7}$

Membaca permulaan merupakan suatu materi yang terdapat pada pelajaran Bahasa Indonesia yang memiliki ruang lingkup dari beberapa aspek seperti: mendengarkan, ${ }^{8}$ membaca, ${ }^{9}$ berbicara, ${ }^{10}$ dan menulis ${ }^{11}$. Upaya tersebut pada peranannya juga mengasah sikomotik halus pada anak. ${ }^{12}$ Idealnya keempat aspek tersebut dilaksanakan secara terpadu. Akan tetapi pelajaran Bahasa Indonesia untuk kelas rendah khususnya di sekolah dasar lebih menekankan pada aspek kemampuan membaca dan kemampuan menulis. Adapun tujuan utama dari membaca yaitu untuk mencari dan menemukan informasi, yang mencangkup isi dan pemahaman makna bacaan ${ }^{13}$. jika menyoal dari materi yang dibahas, maka membaca permulaan merupakan sebuah pembelajaran yang diajarkan di kelas awal dimana notabenenya peserta didik masih belum memahami huruf secara menyeluruh.

Maka dari itu, tidak dapat dipungkiri bahwa pembelajaran membaca permulaan bagi anak yang terjadi di lapangan memiliki

6 Burhan Nurgiyantoro, Sastra Anak Pengantar Pemahaman Dunia Anak, (Yogyakarta:Gadjah Mada University Press. 2018). Hal. 95

7 Ratnasari Dwi Ade Chandra, 'Pengembangan Media Visual Kartu Angka Efektif Untuk Mengenalkan Huruf Vokal A, I, U, E, O Pada Anak Usia Dini 3-4 Tahun Paud Labschool Jember", Jurnal Indria (Jurnal Imiah Pendidikan Prasekolah Dan Sekolah Awal), 2 (1) (2017): 45-71. Link. http://journal.umpo.ac.id/index.php/indria/article/view/447

8 Prana D Iswara, "Pengembangan Materi Ajar Dan Evaluasi Pada Keterampilan Mendengarkan Dan Membaca”, Jurnal Mimbar Sekolab Dasar, 3 (1) (2016): 89-96. Link. http://ejournal.upi.edu/index.php/mimbar/article/ view/2359

9 Ibid. $89-96$

10 Siti Halidjah, "Evaluasi Keterampilan Berbicara dalam Pembelajaran Bahasa Indonesia”, Jurnal Visi Ilmu Pendidikan, 2 (1) (2010): 259-268 Link. http://jurnal.untan.ac.id/index.php/jvip/article/view/367/370

11 Badan Nasional Standar Pendidikan BNSP, Kurikulum Tingkat Satuan Pendidikan (Badan Nasional Standar Pendidikan BNSP, 2006).

12 Maulida Rizqia, Wahyu Iskandar, Nurzakiah Simangunsong, Suyadi Suyadi, "Analisis Psikomotorik Halus Siswa Ditinjau dari Keterampilan Menggambar Anak Usia Dasar SD”, Al-Aulad: Journal of Islamic Primary Education, 2 (2) (2019): 45-53. Link. https://journal.uinsgd.ac.id/index.php/alaulad/article/view/5212/3018 Hal. 9

13 Taringan, Pengajar Ejaan Babasa Indonesia (Bandung: Angkasa, 1979). 
berbagai masalah, seperti: (1) kesulitan anak mengenali huruf, (2) kesalahan membaca pada setiap kata, para frase yang keliru, kesalahan pengucapan, penggunakan gerak bibir, serta penggunaan jari telunjuk dan menggerakkan kepala ${ }^{14}$. Dalam hal ini aktivitas membaca menjadi suatu kegiatan yang rumit bagi anak, karena melibatkan banyak aspek yang menuntut anak untuk tidak hanya melafalkan tulisan namun juga dibarengi dengan melibatkan aktivitas visual, berfikir dan psikolinguistik kognitif. ${ }^{15}$

Saat berusia 4-6 tahun anak mempunyai kepekaan yang baik dalam belajar membaca. ${ }^{16}$ Oleh karenanya pada saat usia demikian peserta didik perlu diberikan rangsangan aktivitas yang dapat membantu anak dalam membaca dan merangsang pintu masuk kecerdasan lainnya. ${ }^{17}$ Mencermati hal ini Maria Montessori yang merupakan tokoh psikologi perkembangan memiliki cara-cara tersendiri untuk mengatasi permasalahan dalam membaca permulaan yang dikenal sebagai metode Montessori ${ }^{18}$. Dalam metode ini peserta didik melakukan aktivitas-aktivitas dengan menggunakan alat atau material untuk menunjang aktivitas belajar anak. ${ }^{19}$ Melalui aktivitas yang dilakukan anak mampu meningkatkan

14 Slamet, Pembelajaran Babasa Dan Sastra Indonesia Di Kelas Rendah Dan Tinggi Sekolah Dasar (Surakarta: UNS Press, 2014), Hal.104-108

15 Farida Rahim, Pengajaran Membaca.., Hal. 2

16 Tisna Umi Hanifah, "Pemanfaatan Media Pop-Up Book Berbasis Tematik Untuk Meningkatkan Kecerdasan Verbal-Linguistik Anak Usia 4-5 Tahun" (Studi Eksperimen Di Tk Negeri Pembina Bulu Temanggung, Early Childhood Education Papers Journal 3 (2) (2014): 46-54. Hal. 48. Link. Https://Journal.Unnes.Ac.Id/Sju/Index.Php/Belia/Article/View/3727

17 Sri Utami Soraya Dewi, "Pengaruh Metode Multisensori Dalam Meningkatkan Kemampuan Membaca Permulaan Pada Anak Kelas Awal Sekolah Dasar", Modeling: Jurnal Program Studi PGMI, 2 (1) (2015): 1-13. Hal. 1. Link. http://www.jurnal.stitnualhikmah.ac.id/index.php/modeling/article/view/43

18 Metode ini berangkat dari italia yang di bangun oleh Maria Montessori. Dalam pengembangan disipilin dan kemandirian anak Montessori selau beranggapan tentang kemerdekaan anak dalam menentukan pilihannya. Dimana Montessori beranggapan bahwa anak tidak akan dapat disiplin dan mandiri jika ia tidak merdeka. Metode montessori juga meenyesuikan kebutuhan sikologis anak dan melibatkan media untuk mencapai pembelajaran yang efektif bagi anak/pesertadidik. Lihat dalam Raisah Armayanti Nasution, "Penanaman Disiplin dan Kemandirian Anak Usia Dini dalam Metode Maria Montessori”, 5 (2) (2017): 1-16. Hal. $6 \mathrm{http://jurnaltarbiyah.uinsu.ac.id/index.php/raudhah/}$ article/view/179/166

19 Grainger, J. Problem Perilaku, Perbatian dan Membaca pada Anak. (Jakarta: PT Gramedia Widiasarana Indonesia, 2003).). Hal. 34 
kemampuan membaca sebagaimana prinsip-prinsip dalam teori Montessori itu sendiri. ${ }^{20}$

Pada konteks ini peneliti menemukan penelitian yang memiliki kemiripan pada sebelumnya terkait metode montessori yang diteliti oleh Aay dengan judul "Upaya Meningkatkan Kemampuan Membaca Permulaan Melalui Metode Montessori pada Siswa Kelas I di SDN Rawamangun 09 Pagi Jakarta Timur" bahwa data yang diperoleh menunjukan bahwa penggunaan metode Montessori dapat meningkatkan kualitas pembelajaran, khususnya pembelajaran membaca permulaan, mengajarkan siswa lebih percaya diri dan berpartisipasi aktif dalam kegiatan pembelajaran, serta mengajarkan siswa lebih disiplin dan teliti dalam perabaan kartu huruf yang terbuat dari kertas kasar. ${ }^{21}$

Data penelitian di atas cukup akurat untuk diakui keabsahannya pada penerapan metode montessori dalam meningkatkan kemampuan membaca permulaan peserta didik. Namun pada kaitan ini artikel ini mencoba untuk memposisikan sebuah polarisasi konsep baru pada metode Montessori dalam kegiatan belajar membaca pada anak kelas rendah. Upaya ini adalah menambahkan sebuah studi analisis tentang metode Montessori dalam kegiatan belajar membaca pada anak kelas rendah. Keterbaruannya dilihat dari analisis perbebedaan yang terdapat pada penambahan material, langkah-langkah, strategi dan materi ajarnya yang diharapkan bisa menjadi sebuah acuan untuk diterapkan 'di uji' pada penelitian selanjutnya terkhusus penelitian lapangan (Field research). Untuk itu analisis kebaruan ini diharapkan juga mampu menambah keberagaman tentang kajian metode montessori.

\section{METODOLOGI PENELITIAN}

Metode penelitian ini menggunakan studi pustaka (library research) yang mengandalkan sumber dari berbagai bibliografi yang mapan seperti artikel ilmiah, skripsi dan buku. Kemudian di integrasikan pada subtansi penelitian atau analisis isi (analysis content). Peneliti menemukan hasil penelitian secara objektif dan sistematis melalui pembacaan data yang mempunyai relevansi dengan tajuk

20 Lihat A.S Lillard, Montessori the Science bebind the Genius (New York: Oxford University, 2005). Hal. 29-33.

21 Aay, "Upaya Meningkatkan Kemampuan Membaca Permulaan Melalui Metode Montessori Pada Siswa Kelas I Di Sdn Rawamangun 09 Pagi Jakarta Timur", Jurnal Ilmiah Pendidikan Guru Sekolah Dasar (JIPGSD) 9 (1) (2016):70-110. Link. http://journal.unj.ac.id/unj/index.php/pgsd/article/view/8011/5688 
dan pokok permasalahan. Pembacaan pemikiran para ahli dengan menggunakan pendekatan integratif dan pemaknaan substansinya.

\section{HASIL DAN DISKUSI}

\section{Biografi Singkat Maria Montessori}

Maria Montessori merupakan tokoh pelopor yang menemukan metode montessori yang lahir pada 31 Agustus $1870^{22} \mathrm{di}$ Provinsi Ancona Italia. ${ }^{23}$ Montessori merupakan anak tunggal dari seorang pebisnis di perusahaan monopoli tembakau yang menjadikannya hidup berkecukupan. ${ }^{24}$ Alessandro montssori adalah ayah dari montessori yang juga seorang militer kuno dengan kebiasaan suka marah. ${ }^{25}$ Awal ketertarikan montessori terhadap anak-anak dimulai ketika ia menempuh pendidikan di Italia dan bekerja dibidang psikiater dan antropologi. Ketertarikan Montessori terhadap dunia anak ia tuangkan dalam pengembangan observasi dalam perawatan anak berkebutuhan khusus dan keterbelakangan mental $^{26}$ dalam karya tulisnya. ${ }^{27}$

\section{Metode Montessori}

Metode montessori pada prinsip sederhana merupakan metode pendidikan untuk anak yang dalam penyusunannya didasari dengan teori perkembangan anak itu sendiri. Metode ini menekankan pada stimulasi terhadap seluruh indra ${ }^{28}$ yang dimiliki anak dengan karakteristik penekanan terhadap adaptasi lingkungan

22 Rita Kramer, Maria Montessori: A Biography, (Mass: Perseus Book, 1998).Hal. 22.

23 Maria Montessori, Metode Montessori: Panduan Wajib Ntuk Guru dan Orang Tua Didik PAUD (Pendidikan Anak Usia Dini), Terj. Ahmad Lintang Lazuardi, (Yogyakarta: Pustaka Pelajar, 2013). Hal. 1

24 Suvidian Elytasari, "Esensi Metode Montessori dalam Pembelajaran Anak Usia Dini”, Jurnal Bunayya, 3 (1) (2017), Hal. 3. Link. Https://Jurnal.ArRaniry.Ac.Id/Index.Php/Bunayya/Article/View/2045/1516

25 Indah Fajarwati, "Konsep Montessori Tentang Pendidikan Anak Usia Dini dalam Perspektif Pendidikan Islam”, Jurnal Pendidikan Agama Islam, 11 (1) (2014): 37-52. Link. Https://Media.Neliti.Com/Media/Publications/117909-IDKonsep-Montessori-Tentang-Pendidikan-Ana.Pdf

26 Lesley Britton, "Montessori Play \& Learn: A Parents Guide To Purposeful Play From Two To Six," (New York: Crown Publisher, Inc. 1992), Hal. 10.

27 Ag. Soejono, "Aliran Baru dalam Pendidikan",(Bandung: CV. Ilmu, 1987), Hal. 78.

28 Maria montessori, , "Rahasia Masa Kanak-Kanak", Terj. Ahmad Lintang lizuardi (Yogyakarta: Pustaka Pelajar, 2016). Hal. 163. 
pada tingkat perkembangan kemampuan berfikir ${ }^{29}$ dengan tujuan menemukan watak alami anak serta untuk memberikan kebebasan. ${ }^{30}$ $\mathrm{Hal}$ ini dikarenakan Montessori menganggap anak merupakan individu unik yang berhak melakukan sesuatu ataupun tidak. ${ }^{31}$

Pada kaitan ini, aktivitas yang dilakukan sangat berperan untuk membantu pemahaman konsep yang ditanamkan pada peserta didik melalui pembelajaran sehingga peserta didik memperoleh kemampuan praktis. Montessori megutarakan bahwa proses pendidikan harus disesuaikan dengan perkembangan anak berdasarkan usia tertentu dengan cara memperhatikan tahap perkembangan individu $a_{n a k}{ }^{32}$. Montessori mengindentifikasikan periode perkembangan secara umum menjadi tiga bagian diantaranya:

a. Absorbent mind (0-6 tahun). Pada periode absorbent mind ini, anak mampu menyerap informasi dengan cepat dan menciptakan konsep pemahaman melalui pengalaman lingkungan, menggunakan bahasa, dan muncul secara perlahan terus berkembang dengan cara dilatih, diperkuat, disempurnakan, dan terus dikembangkan. Proses penyerapan terjadi sejak masa kelahiran hingga usia 6 tahun. Pada masa tersebut anak akan menyerap setiap pengalaman dari ingkungan sekitar melalui indera dan diolah di dalam otak sehingga akan berpengaruh pada perkembangan kekuatan mental bawaannya. ${ }^{33}$

b. Periode usia 6-12 tahun (periode kedua), Montessori disebut sebagai periode masa anak-anak.

c. Periode usia 12-18 tahun (periode ketiga). Periode ketiga, seiring dengan usia remaja, terjadi perubahan fisik yang cukup besar dan menuju kematangan yang sempurna. Pada saat remaja setiap individu akan mencoba untuk memahami peran sosial maupun

29 Miftakhul Jannah, "Studi Komparasi Pemikiran Maria Montessori dan Abdullah Nashih Ulwan Tentang Metode Pendidikan Anak dalam Keluarga", digilib.uinsby. 2018, Hal. 56. Link. http://digilib.uinsby.ac.id/25974/

30 Maria montessori, Metode Montessori, Terj. Ahmad Lintang lizuardi (Yogyakarta: Pustaka Pelajar, 2016), Hal. 72.

31 Vidya Dwina Paramita, Jatuh Hati Pada Montessori, (Yogyakarta: PT. Bentang Pustaka, 2017), Hal. 57.

32 Maria Montessori, The Absorbent Mind (Pikiran Yang Mudah Menyerap) (Yogyakarta: Pustaka Pelajar, 2008), Hal.2

33 Jaipul L Roopnaire, James E Jhinson, pendidikan Anak Usia Dini: dalam Berbagai Pendekatan, (Jakarta: Prenada Media Group, 2015), Hal. 368. 
ekonomi dengan mencoba menemukan posisinya di tengah masyarakat ${ }^{34}$

Selanjutnya pada tahapan permulaan atau absorbent mind montessori juga menjabarkan pikiran menyerap (the absorbent mind) merupakan aktivitas menerima segala informasi yang didapat tanpa menyadari akan proses ini. Kreatifitas alami dari kapasitas belajar yang terdapat dalam diri anak dinamakan pikiran menyerap (absorbent mind) dan diperoleh dari beberapa fase perkembangan fisik atau disebut sebagai periode sensitif. ${ }^{35}$ Proses nomalisasi merupakan teori utama yang dipakai untuk memahami cara belajar anak sebagai pelengkap dalam menentukan sebuah hakikat. Pata tahap ini, montessori membagi periode sensitif dibagi menjadi enam tahapan yang dituangkan dalam tabel di bawah ini: ${ }^{36}$

\section{Tabel 1: Tabel periode perkembangan anak}

\begin{tabular}{|c|c|c|}
\hline \multicolumn{2}{|r|}{ No Periode Sensitif } & Perkembanngan Anak \\
\hline 1 & $\begin{array}{l}\text { Periode sensitif/peka } \\
\text { untuk keteraturan (usia } \\
0-3 \text { tahun }\end{array}$ & $\begin{array}{l}\text { Tahap ini anak sangat sentisitif terhadap } \\
\text { keteraturan. Ketika anak sudah mulai } \\
\text { bergerak dan berpindah ke tempat lain serta } \\
\text { menyerap aktivitas melalui indera, maka } \\
\text { anak membutuhkan arahan. Arahan yang } \\
\text { diterima akan diserap sehingga anak akan } \\
\text { cenderung meletakkan sesuatu sesuai } \\
\text { dengan tempatnya. }\end{array}$ \\
\hline 2 & $\begin{array}{l}\text { Periode sensitif untuk } \\
\text { hal yang detail dan } \\
\text { memfokuskan } \\
\text { perhatiannya pada hal } \\
\text { yang kecil (usia 1-2 tahun) }\end{array}$ & $\begin{array}{l}\text { Pada tahap ini anak mulai mampu } \\
\text { mendeteksi dan menemukan hal-hal kecil } \\
\text { misalnya anak lebih detail melihat adanya } \\
\text { serangga kecil yang mungkin tidak } \\
\text { diperhatikan oleh orang dewasa., Ketika } \\
\text { mereka melihat suatu objek gambar, secara } \\
\text { tidak sengaja mereka akan mengabaikan } \\
\text { objek gambar yang paling utama dan } \\
\text { teralihkan untuk memperhatikan hal kecil } \\
\text { yang berada di latar belakang objek } \\
\text { gambar utama. }\end{array}$ \\
\hline
\end{tabular}

34 G.L Gutek, The Montessori Method: The Origin Of An Educational Innovation, Including An Annotated Edition Of Maria Montessori's The Montessori Method. (Lenham Rowman \& Littlegfield Publisher, 2004), Hal. 49-50

35 Elizabeth G.Hainstock, Kenapa Montessori (Jakarta: P.T. Pustaka Delapratasa, n.d.), Hal.33

36 Suvidian Elytasari, "Esensi Metode Montessori Dalam Pembelajaran Anak Usia Dini”, Jurnal Bunayya, 3 (1), (2017), Hal. 66. Link. Https://Jurnal.ArRaniry.Ac.Id/Index.Php/Bunayya/Article/View/2045/1516 


\begin{tabular}{|c|c|c|}
\hline 3 & $\begin{array}{l}\text { Periode sensitif dalam } \\
\text { hal menggunakan } \\
\text { tangan / konsisten } \\
\text { dalam menggenggam } \\
\text { setiap benda yang } \\
\text { disentuhnya (usia } 18 \\
\text { bulan - } 3 \text { tahun) }\end{array}$ & $\begin{array}{l}\text { Pada tahap ini anak tertarik pada aktivitas } \\
\text { membuka dan menutup benda benda } \\
\text { dengan menggunakan telapak tangannya. } \\
\text { Contohnya seperti: Aktivitas yang } \\
\text { dilakukan dengan memasukan benda ke } \\
\text { dalam sebuah wadah, lalu menuangkan } \\
\text { dan memasukkan kembali benda yang ada } \\
\text { dalam genggamannya tersebut. }\end{array}$ \\
\hline 4 & $\begin{array}{l}\text { Periode sensitif untuk } \\
\text { movement/gerakan( } \\
\text { usia 1,5-4tahun) }\end{array}$ & $\begin{array}{l}\text { Periode sensitive merupakan periode } \\
\text { kepekaan yang paling terlihat ketika anak } \\
\text { mulai berjalan. Pada tahap ini anak } \\
\text { terkoordinasi pada perkembangan otot } \\
\text { serta berminat terhadap benda kecil. } \\
\text { Kekuatan gerakan minat anak pada } \\
\text { kebenaran dan realitas menyadari urutan } \\
\text { dalam waktu dan ruang seperti Anak-anak } \\
\text { terdorong oleh implus yang tidak bisa } \\
\text { dilawan dengan keinginanan mereka. }\end{array}$ \\
\hline 5 & $\begin{array}{l}\text { Periode sensitif untuk } \\
\text { belajar bahasa } \\
\text { a. Secara tidak sadar } \\
\text { (usia } 3 \text { bln - } 3 \text { thn). } \\
\text { b. Secara sadar (usia } 3 \text { - } \\
\text { 6 tahun) }\end{array}$ & $\begin{array}{l}\text { Pada periode ini anak belajar berbagai } \\
\text { kata-kata, dan tata bahasa dari } \\
\text { lingkungannya. Anak- mulai suka } \\
\text { mengoceh dengan kata kata tidak karuan } \\
\text { terlebih dahulu sebelum anak dapat } \\
\text { berbicara dengan kata-kata yang } \\
\text { bermakna. Setelah itu anak masuk pada } \\
\text { tahapan memadukan "kalimat dua kata," } \\
\text { baru. }\end{array}$ \\
\hline 6 & $\begin{array}{l}\text { Peride sensitif untuk } \\
\text { Aspek Kehidupan } \\
\text { Sosial ( } 3-6 \text { tahun) }\end{array}$ & $\begin{array}{l}\text { Periode kepekaan ditandai dengan anak } \\
\text { yang mulai 'aware'dengan teman satu } \\
\text { grup. Saat mereka menyadari itu mereka } \\
\text { mulai belajar bekerja sama dengan yang } \\
\text { lain. }\end{array}$ \\
\hline
\end{tabular}

Sumber: (Montessori, 1964)

\section{Membaca Permulaan}

Tzu dalam Ahmad Susanto menjelaskan bahwa membaca merupakan suatu kemampuan dalam menerjemahkan lambang huruf yang ada ke dalam bentuk suara yang digabungkan dengan beberapa kata-kata sehingga rangkaian yang tersusun tersebut dapat dipelajari dan dipahami ${ }^{37}$. Selain itu, membaca permulaan

37 Ahmad Susanto, Perkembangan Anak Usia Dini: Pengantar Dalam Berbagai Aspeknya (Jakarta: Kencana, 2011). Hal. 83. 
merupakan aktivitas pengenalan simbol ${ }^{38}$ melalui penggunaan bahasa ${ }^{39}$ untuk mencari makna dalam sebuah tulisan. ${ }^{40}$

Merujuk pada teori tentang praktik pengajaran membaca yang diutarakan oleh Rubin dalam Slamet, ia merincikan prinsip-prinsip pembelajaran yang harus diperhatikan. Adapun prinsip tersebut adalah sebagai berikut: (1) kesadaran fonem (bunyi bahasa), (2) peningkatan ucapan (3) interelasi antar huruf merupakan kualifikasi yang menentukan dalam membaca, (4) memahami variasi bunyi merupakan kemampuan vital dalam memproduksi bahasa, terkhusus dalam membaca,(5) melatih daya ingat atau keahlian sensoris, (6) mencermati perbedaan huruf, (7) melatih daya pikir ke kiri dan ke kanan, (8) terampil dalam memahami, dan (9) memperkaya kosakata ${ }^{41}$.

\section{Implementasi Metode Montessori pada Mata Pelajaran Bahasa Indonesia Kelas Rendah}

Bahasa Indonesia menjadi salah satu mata pelajaran yang bertujuan untuk dapat melatih anak dalam belajar membaca pada kelas rendah, oleh karena itu pembelajaran membaca pada tahap ini bukanlah hal yang mudah sehingga mendapat perhatian khusus bagi guru kelas I dalam menyusun perencanaan pelaksaan pembelajaran, Metode Montessori merupakan satu metode yang dapat diimplementasikan dalam pembelajaran khususnya pada bab pertama untuk kelas 1 berikut: ${ }^{42}$
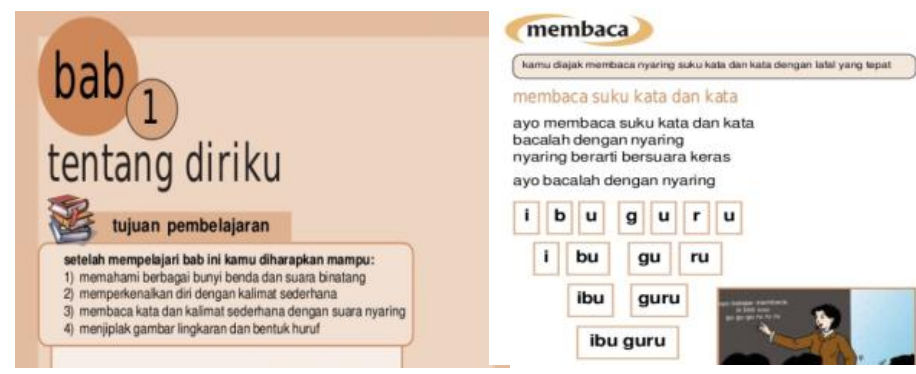

Gambar 1. Materi pengenalan huruf dalam pelajaran Bahasa Indonesia

38 Mulyono Abdurrahman, Pendidikan bagi Anak Berkesulitan Belajar, (Jakarta: Rineka Cipta, 2003). Hal. 200.

39 Lesley Mandel Morrow, Literacy Development in the Early Years, (United State of America : Allyn and Bacon, 1993). Hal. 66.

40 Tampubolon, Mengembangkan Minat dan Kebiasaan Membaca pada Anak, (Bandung: Angkasa, 1993). Hal. 66

41 Slamet, Pembelajran Babasa dan Sastra Indonesia di Kelas Rendah dan Tinggi Sekolah Dasar (Surakarta: UNS Press, 2014). Hal. 107.

42 Umri Nur'aini dkk, Bahasa Indonesia untuk Kelas 1 SD/MI Jakarta: Depertermen Pendidikan Nasional, 2008). h 1 
Pada Metode Montesori pada penerapannya dikaitkan dalam proses pembelajaran. Sebelum siswa diperkenalkan untuk belajar membaca guru harus mampu menumbuhkan rasa senang sehingga anak tertarik dan menyukai kegiatan membaca. Hal ini sesuai dengan prinsip metode montessori sendiri yang mana pentingnya interaksi guru dalam belajar membaca sangat dibutuhkan. Pada tahap ini guru harus lebih dulu membangun kedekatan dengan siswa sehingga siswa merasa lebih aman dan nyaman terlebih dahulu dalam belajar.

Upaya membangun kedekatan dan ketertarikan siswa untuk belajar dapat berupa guru mengajak siswa bernyanyi dengan melakukan nyanyian phonic song yang mana jika guru menyebutkan huruf A berati Apel B berati Bola dan begitu seterusnya pada tahap selanjutnya peran guru dibutuhkan untuk memberikan berbagai aktivitas-aktivitas sebagai rangsangan pada anak unuk belajar karena pada usia kelas 1 SD anak masuk pada periode Operasional Konkrit, maka dari itu untuk proses belajar membaca guru dapat memberikan berbagai macam material konkrit yang dapat digunakan siswa dalam proses belajar misalnya guru memperkenalkan huruf dengan dengan menggunakan sandpaper letter yang merupakan huruf timbul yang bersifat konkrit yang dapat digunakan untuk meraba huruf. Dalam hal ini siswa dapat merasakan rabaan huruf dan akan mudah mengingat bentuk pada setiap huruf yang dipelajari untuk belajar membaca. Sandpaper letter ini dapat dibuat sendiri oleh guru dengan menggunakan bahan karton bekas sehingga ramah lingkungan.

Apabila pengenalan huruf tadi sudah mampu dikuasai anak maka guru dapat membrikan berbagai aktivitas lainnya dengan memberikan tugas lainnya. Dalam belajar membaca untuk kelas 1 jika siswa sudah mulai dapat mengenal huruf, selanjutnya guru dapat memberikan berbagai gambar atau benda konkrit yang berakitan langsung dengan kata yang dipelajari. Dalam pembelajaran ini jika guru menunjukkan gambar ibu guru maka siswa diajak untuk dapat menyusun huruf sandpaper letter tadi disusun huruf I-B-U G-U-R-U, pada tahap ini siswa akan merasa senang untuk menyusun setiap huruf dengan berbatuan gambar. Jika anak sudah mampu menyusun setiap huruf menjadi kata, maka selanjutnya guru dapat mengajak siswa untuk mencocokan berbagai macam gambar dengan kata-kata yang telah dipersiapkan oleh guru. Beberapa hal tersebut dapat di sesuaikan dengkan kebutuhan anak jika mengalami kesulitan dalam mengingat huruf dalam proses belajar membaca. 


\section{KESIMPULAN}

Adapun hasil penelitian ini menunjukkan bahwa metode Montessori dalam meningkatkan kemampuan membaca yakni: (1) memberikan pola baru dalam merangsang pemahaman dalam membaca permulaan anak/peserta didik, (2) memberikan konsep dalam penguatan daya serap (absorbent mind) membaca permulaan anak/peserta didik, (3) memenuhi kebutuhan pada periode sensitif serta struktur intelektual dalam belajar membaca permulaan anak/peserta didik, (4) Pengembangan material baru pada metode Montessori dalam pembelajaran Bahasa Indonesia yang konkrit untuk meningkatkan kemampuan membaca permulaan anak/peserta didik.

\section{DAFTAR PUSTAKA}

Abdurrahman Mulyono. (2003). Pendidikan bagi Anak Berkesulitan Belajar, Jakarta: Rineka Cipta

Aay, "Upaya Meningkatkan Kemampuan Membaca Permulaan Melalui Metode Montessori Pada Siswa Kelas I Di Sdn Rawamangun 09 Pagi Jakarta Timur", Jurnal Ilmiah Pendidikan Guru Sekolah Dasar (JIPGSD) 9 (1) (2016):70-110. Link. http://journal.unj.ac.id/unj/ index.php/ pgsd/article/view/8011/5688

Badan Nasional Standar Pendidikan BNSP, (2006). Kurikulum Tingkat Satuan Pendidikan. Badan Nasional Standar Pendidikan BNSP.

Britton Lesley, (2006), "Montessori Play \& Learn: A Parents Guide To Purposeful Play From Two To Six,” New York: Crown Publisher, Inc. x

Chairunnisa, "Pengaruh Literasi Membaca Dengan Pemahaman Bacaan" (Penelitian Survei Pada Mahasiswa STKIP Kusumanegara Jakarta), Jurnal Pendidikan Bahasa Sekolah Pascasarana, 6 (1) (2017): 745-756. Link. http://jurnal.unswagati.ac.id/index.php/jurnaltuturan/article/ view/1584/963

Carol, Seefeldt, Barbara A. (2008). Wasik. Pendidikan Anak Usia Dini Menyiapkan Anak Usia Tiga, Empat, Dan Lima Tabun Masuk Sekolah. (Jakarta: PT Indeks)

Dewi Sri Soraya Utami, "Pengaruh Metode Multisensori Dalam Meningkatkan Kemampuan Membaca Permulaan Pada Anak Kelas Awal Sekolah Dasar", Modeling: Jurnal Program Studi PGMI, 2 (1) (2015): 1-13. Link. http://www.jurnal.stitnualhikmah.ac.id/ index.php/modeling/article/view/43

D Iswara Prana, "Pengembangan Materi Ajar Dan Evaluasi Pada Keterampilan Mendengarkan Dan Membaca", Jurnal Mimbar Sekolah Dasar, 3 (1) (2016): 89-96. Link. http://ejournal.upi.edu/index.php/ mimbar/article/view/2359

Elizabeth G.Hainstock. Kenapa Montessori. Jakarta: P.T. Pustaka Delapratasa, n.d. 
Elytasari Suvidian, "Esensi Metode Montessori dalam Pembelajaran Anak Usia Dini”, Jumal Bunayya, 3 (1) (2017). Link. https://Jurnal.ArRaniry.Ac.Id/Index.Php/Bunayya/Article/View/2045/1516

Epcacan, C. (2010). Socio Economic And Cultural Factors Effecting Self Efficacy On Reading Comperehension, (Procedia Social And Behavioral Sciences)

Fajarwati Indah, "Konsep Montessori Tentang Pendidikan Anak Usia Dini dalam Perspektif Pendidikan Islam", Jurnal Pendidikan Agama Islam, 11 (1) (2014): 37-52. Link. Https://Media.Neliti.Com/Media/ Publications/117909-ID-Konsep-Montessori-Tentang-PendidikanAna.Pdf

Farida Rahim. (2005). Pengajaran Membaca Di Sekolah Dasar. Jakarta: PT Bumi Aksara.

Gutek, G.L. The Montessori Method: The Origin Of An Educational Innovation, Including An Annotated Edition Of Maria Montessori's The Montessori Method. Lenham Rowman \& Littlegfield Publisher, 2004.

Grainger, J. (2003). Problem Perilaku, Perhatian dan Membaca pada Anak. (Jakarta: PT Gramedia Widiasarana Indonesia)

Halidjah Siti, "Evaluasi Keterampilan Berbicara dalam Pembelajaran Bahasa Indonesia", Jumal Visi Ilmu Pendidikan, 2 (1) (2010): 259-268 Link. http://jurnal.untan.ac.id/index.php/jvip/article/view/367/370

HD Nugraha, S Ameliola, "Perkembangan Media Informasi Dan Teknologi Terbadap Anak Dalam Era Globalisasi”, (2013). Link. http:/ /www.academia.edu/download/34462625/2013-02-29.pdf Diakses 12 September 2014.

Jannah Miftakhul, "Studi Komparasi Pemikiran Maria Montessori dan Abdullah Nashih Ulwan Tentang Metode Pendidikan Anak dalam Keluarga", digilib.uinsby. 2018, Hal. 56. Link. http:/ /digilib.uinsby.ac.id/25974/

Kramer Rita. (1998). Maria Montessori: A Biography, Mass: Perseus Book.

Lillard, A.S. (2005). Montessori the Science behind the Genius. New York: Oxford University.

Matlin, Margaret W. Cognition, (Northwestern University: Wiley, 2008).

Montessori Maria. (2008). The Absorbent Mind Pikiran Yang Mudah Menyerap). Yogyakarta: Pustaka Pelajar

Montessori Maria. (2013). Metode Montessori: Panduan Wajib untuk Guru dan Orang Tua Didik PAUD (Pendidikan Anak Usia Dini), Terj. Ahmad Lintang Lazuardi, Yogyakarta: Pustaka Pelajar.

Montessori Maria. (2016). Rahasia Masa Kanak-Kanak, Terj. Ahmad Lintang lizuardi, Yogyakarta: Pustaka Pelajar.

Morrow Lesley Mandel, (1993), Literacy Development in the Early Years, United State of America : Allyn and Bacon.

Nur'aini Umi dkk. (2008). Bahasa Indonesia untuk Kelas 1 SD/MI Jakarta: Depertermen Pendidikan Nasional.

Nurgiyantoro Burhan, (2018) Sastra Anak Pengantar Pemahaman Dunia Anak, (Yogyakarta:Gadjah Mada University Press). 
Paramita Dwina Vidya. (2017). Jatub Hati Pada Montessori, Yogyakarta: PT. Bentang Pustaka

Pratiwi, Ema. "Pembelajaran Calistung Bagi Anak Usia Dini Antara Manfaat Akademik Dan Resiko Menghambat Kecerdasan Mental Anak". Prosiding Seminar Nasional Pendidikan "Inovasi Pembelajaran Untuk. Pendidikan Berkemajuan" Fkip Universitas Mubammadiyah Ponorogo, 7 November 2015:278-283. Link.. http://seminar.umpo.ac.id/ index.php/semnasdik2015/article/viewFile/231/231

Ratnasari Dwi Ade Chandra, 'Pengembangan Media Visual Kartu Angka Efektif Untuk Mengenalkan Huruf Vokal A, I, U, E, O Pada Anak Usia Dini 3-4 Tahun Paud Labschool Jember”, Jurnal Indria Jurnal Ilmiah Pendidikan Prasekolah Dan Sekolah Awal), 2 (1) (2017): 45-71. Link. http://journal.umpo.ac.id/index.php/indria/article/view/447

Rizqia Maulida, Iskandar Wahyu, Simangunsong Nurzakiah, Suyadi Suyadi, "Analisis Psikomotorik Halus Siswa Ditinjau dari Keterampilan Menggambar Anak Usia Dasar SD”, Al-Aulad: Journal of Islamic Primary Education, 2 (2) (2019): 45-53. Link. https://journal.uinsgd.ac.id/ index.php/al-aulad/article/view/5212/3018

Rolldan. Aurora H. (1975). College Reading And Writing, (Greenhill: Reading Dinamics)

Roopnaire Jaipul L, James E Jhinson. 2015 Pendidikan Anak Usia Dini: dalam Berbagai Pendekatan, Jakarta: Prenada Media Group.

Slamet. (2014). Pembelajran Bahasa Dan Sastra Indonesia di Kelas Rendah dan Tinggi Sekolah Dasar. Surakarta: UNS Press.

Susanto Ahmad,(2011). Perkembangan Anak Usia Dini: Pengantar dalam Berbagai Aspeknya. (Jakarta: Kencana).

Soejono. Ag. (1987). Aliran Baru dalam Pendidikan, (Bandung: CV. Ilmu).

Tampubolon, 1993, Mengembangkan Minat dan Kebiasaan Membaca pada Anak, Bandung: Angkasa,

Taringan. (1979). Pengajar Ejaan Bahasa Indonesia. (Bandung: Angkasa).

Umam Khotibul Aguswan, "Dukungan Lingkungan Literasi Keluarga Muslim Terhadap Perkembangan Kemampuan Membaca Latin Dan Arab (Alqur'an) Serta Perkembangan Akademik Anak", Elementary: Jumal Ilmiah Pendidikan Dasar, 2 (1) (2016): 1-12. Link. http:/ /e-journal.metrouniv.ac.id/index.php/elementary/ article/view/ dukungan-lingkungan-literasi-keluarga-muslim-terhadapperkembangan-kemampuan-membaca-latin-dan-alqur\%92an-sertaperkembangan-akademik-anak

Umi Hanifah Tisna, "Pemanfaatan Media Pop-Up Book Berbasis Tematik Untuk Meningkatkan Kecerdasan Verbal-Linguistik Anak Usia 4-5 Tahun" (Studi Eksperimen Di Tk Negeri Pembina Bulu Temanggung, Early Childhood Education Papers Journal 3 (2) (2014): 46-54. Link. Https://Journal.Unnes.Ac.Id/Sju/Index.Php/Belia/Article/View/372 7 